\title{
DEFORMABILITY PARAMETERS OF VARVED CLAYS FROM THE IŁÓW (CENTRAL POLAND) AREA BASED ON THE SELECTED FIELD TESTS
}

\author{
PIOTR ZBIGNIEW ZAWRZYKRAJ \\ University of Warsaw, Faculty of Geology, Institute of Hydrogeology and Engineering Geology, \\ e-mail: Piotr.Zawrzykraj@uw.edu.pl
}

\begin{abstract}
This publication presents the results of research carried out for the ice-dammed clays of the Iłów region, formed during Vistula glaciation. Pressuremeter tests, dilatometer tests and static probes were made. The tests were performed on the study site in Piskorzec near Iłów. In this region, ice-dammed clays are present almost from the land surface reaching the thickness of about $11 \mathrm{~m}$. This site is the westernmost experimental site of clays of the "Warsaw Ice-Dammed Lake" among those presented in the literature. Research and their analysis showed differences in deformability due to the test procedure in connection with the structure of varved clays. Pressuremeter test, even though it is the most time consuming and challenging among the tests performed, allows the most complete characteristics of deformability of varved clays to be obtained. Vertical profile of clays being studied appears to be fairly homogeneous in terms of mechanical properties. Nevertheless, some parts of the profile clearly differ from the average values. This indicates the rate of post sedimentary changes varied in different parts of research profile. The data obtained are consistent with the values for ice-dammed clays from Radzymin and Sochaczew areas. Comparison of the engineering properties of varved clays to other experimental sites points to their similar geological history. It confirms that the experimental sites belong to one ice-dammed lake covering the areas of the Warsaw Basin.
\end{abstract}

Key words: deformation, pressuremeter test, dilatometer test, in situ tests, varved clays

\section{INTRODUCTION}

This paper deals with ice-dammed clays of the Iłów area (Central Poland). These sediments were deposited during the transgression and the stagnation of a continental glacier of the Vistula Glaciation, when the so-called "Warsaw Basin" (Dzierżek (ed.) 2001) was formed on the glacier's foreland (Fig. 1).

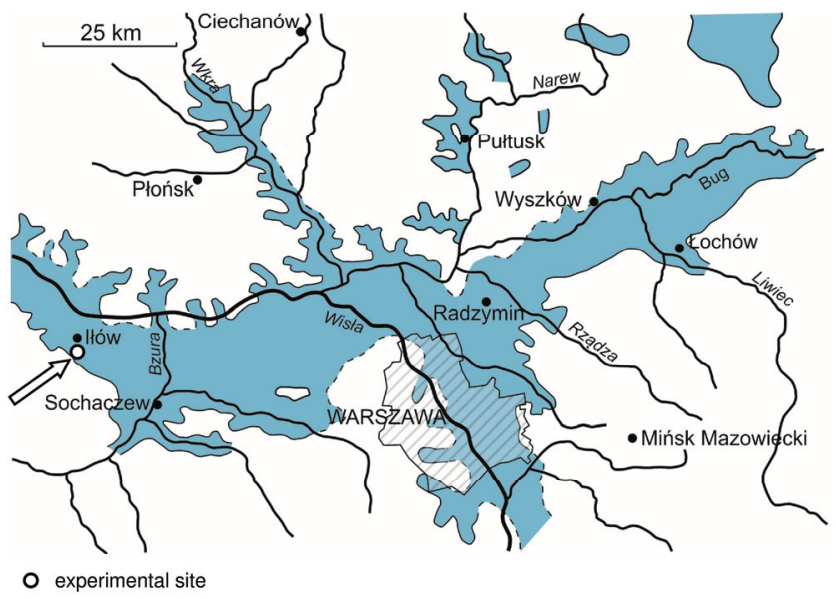

Fig. 1. Warsaw Ice-Dammed Lake (blue) after Różycki (1967)
These deposits are developed in the form of fat varved clays, horizontally laminated, and reflect the specific conditions of their sedimentation (Myślińska 1965, Merta 1978). Mineral material was delivered during a short period of warming, and then slow sedimentation and segregation of the material occurred. A light layer (silty sand) accumulated first. During the winter there was stagnation of the delivered material and a dark layer (clayey) accumulated. The thickness of these sediments in the Warsaw area reaches 16 meters.

This publication is the integral part of a broader research program. It focuses on linking the variability of physical and mechanical properties with the facies variability of ice-dammed clays from the Warsaw Basin. The relationship between the structure of varved clays and their geological engineering properties is the main criterion for the research program. Advanced in situ test methods are an important element in assessing the relationship between the clay parameters and conditions of their sedimentation (Wierzbicki et al. 2006, Wierzbicki et al. 2007). Information derived from the obtained correlation allows us to formulate hypotheses not only about the cohesion or structural variation of varved clays but also about the extent of glaciolacustrine reservoirs. 
Discussion of the sources and the transport direction of sediments may be conducted through the analysis of the regional variation of these parameters. Compiled physical and mechanical parameters of ice-dammed clays collected in several experimental sites will allow for the implementation of the research program.

Clays are fairly common in Mazovia (Fig. 1). Study of the engineering geological properties of clays determined by modern research allows to compare these clays in particular areas and leads to establishment of their regional characteristics and new relationships. This is a new, innovative look at the facies and structural variability from the perspective of engineering geological characteristics.

Engineering geological analysis increases the spectrum of geological characteristics of extra glacial deposits adding to it information about the diagenesis, structure and its deformation, and many others. Characteristic physical and mechanical properties will be used in the implementation of construction projects.

The aim of this study is to present the parameters characterizing the deformability of varved clays in the Iłów area obtained from in situ tests. The collected data will be used to analyze the behaviour of clays as a subsoil. It will also become a tool for geological analysis referring to the regional variability of properties of clays from the Warsaw Ice-Dammed Lake.

\section{STUDY SITE}

In situ tests were carried out in Piskorzec near Iłów (Fig. 2), where a layer of varved clays was documented (Kozydra et al. 1977) for the purpose of the building ceramics industry. Based on the documentation, the thickness of the clays, recognized as the deposit, ranges from 4.1 to $10.2 \mathrm{~m}$. The cohesive ice-dammed series is from 8.9 to $13.5 \mathrm{~m}$ thick $(10.8 \mathrm{~m}$ on average) and is represented mainly by chocolate brown and gray varved clays. The catalogue is the only published data available.

The lithological column (Fig. 3) starts with saturated gray fine sands. The main series of varved clays occurs from the depth of approximately $12.0 \mathrm{~m}$ to $0.5-1.0 \mathrm{~m}$. They are varved grey clays of variable thickness of the varves. At a depth of $4.0 \mathrm{~m}$ there is a characteristic layer of grey fine clayey sand, $20 \mathrm{~cm}$ thick. The clays are overlain by fluvial and aeolian yellow fine-grained sands and silty sands.

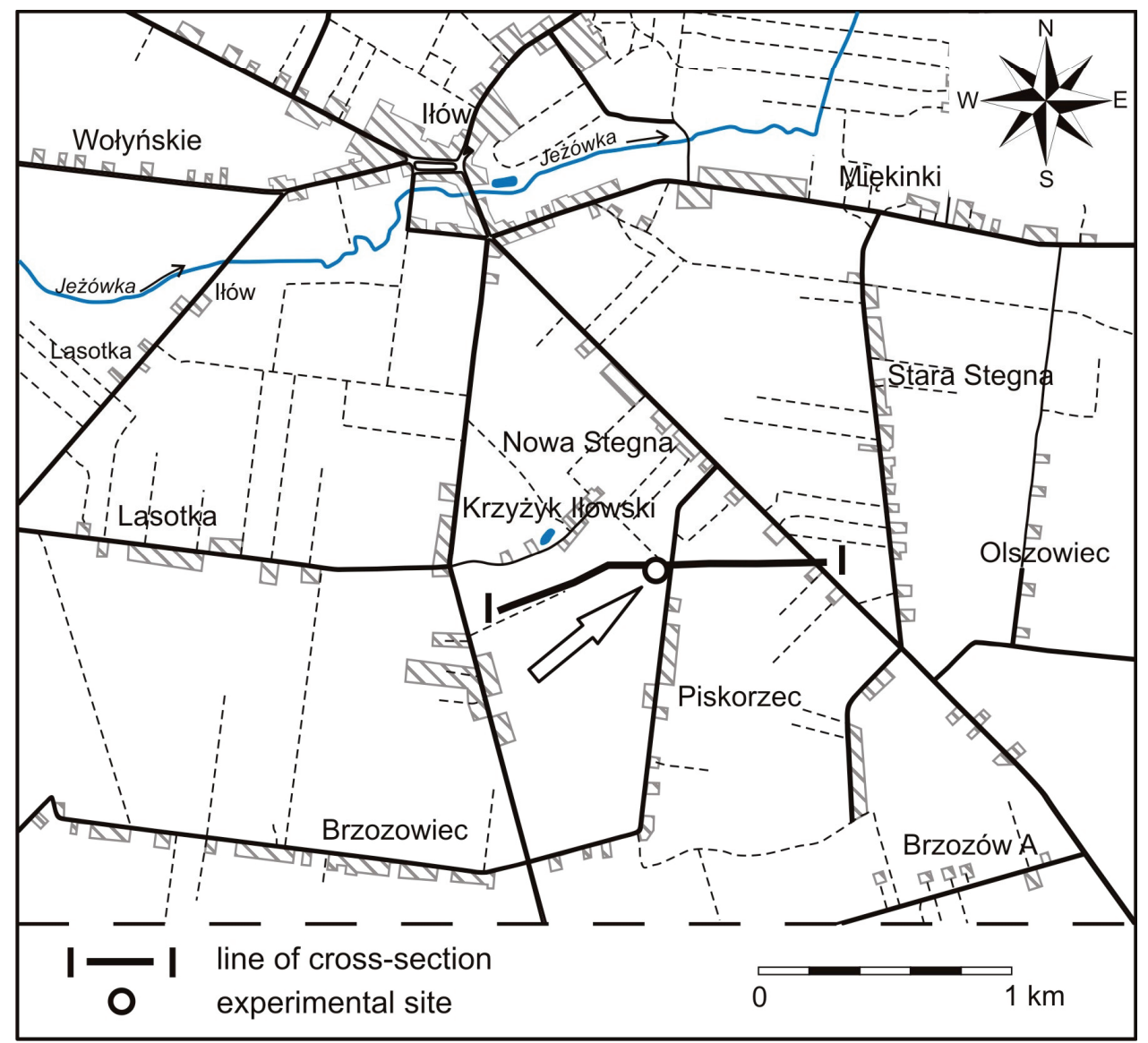

Fig. 2. Location of the study area 


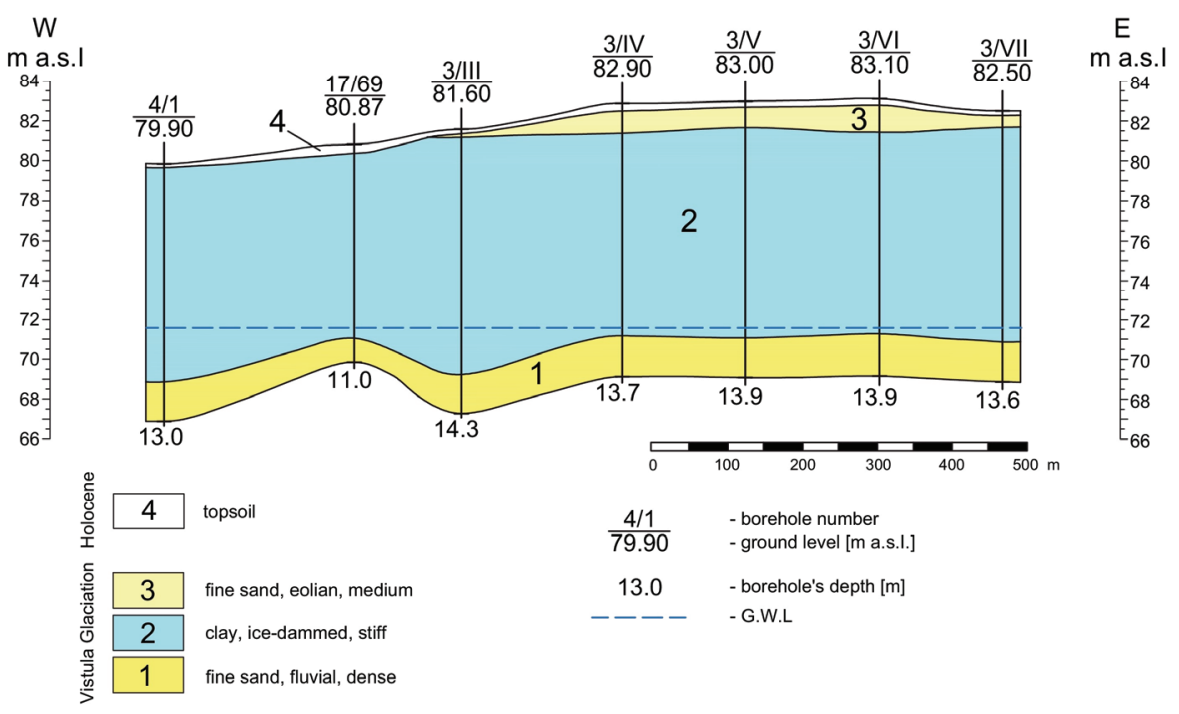

Fig. 3. Geological cross-section (scheme)

\section{MATERIALS AND METHODS}

Basic geological characteristics of the clays under study (type of deposits, thickness, consistency and groundwater level) were determined on the basis of borehole data.

Pressuremeter tests (PMT) were conducted on the experimental site and then compared with the results of flat dilatometer tests (DMT) and static probe tests (CPT). Conducting the pressuremeter test requires most attention among these tests. As emphasized by various researchers (e.g., Baguelin 1978, Frankowski 2003, Tarnawski 1985, 2007), the key issue is to prepare a borehole of appropriate quality. Deformability characteristics for a wide range of loads can be obtained from the Menard Pressuremeter test. This is a device with a large research potential, allowing a number of physical and mechanical soil properties to be obtained in appropriate operation modes (Gambin et al. 2005). The test procedure simulates gradual loading of the soil until the destruction of its structure is observed. The results characterize the reaction of the wall of a borehole (soil surrounding the probe) at increment steps of pressure in the probe. It results in a pressuremeter curve, which illustrates the behaviour of the test soil in a wide range of pressures (load). This is a load test in the borehole.

The $\mathrm{G}$ pressuremeter of APAGEO, equipped with an electronic registration system GeoSPAD, was used in the field. The probe of $58 \mathrm{~mm}$ in diameter (BX) and original hand auger of APAGEO were used in the test. Drilling was carried out manually, in dry conditions, each borehole section was drilled above the planned depth of a particular test. The saturated sands, occurring in the roof of the clays, were cut by the casing pipe.

For the interpretation of the basic parameters, XPressio software was used. The pressuremeter test allows the following parameters in vertical profile to be determined:

- pressuremeter modulus $E_{m}$,

- creep pressure $p_{f}$,

- limit pressure $p_{l}$,

- horizontal stress $\sigma_{h s}$.

The dilatometer test (DMT) allows the assessment of many soil parameters, but is particularly useful because of the reliable assessment of compressibility modulus and the horizontal component of the stress existing in the soil. During the tests, in addition to the above, it is also possible to determine overconsolidation ratio, and to predict the soil type in the geological profile.

The static probe test (CPT) is one of the most widely used in situ test methods of soil properties. Standardized cone resistance $q_{c}$ and sleeve friction $f_{s}$ are registered during the test with a resolution of $20 \mathrm{~cm}$. The analyses included also a test with an electric cone with pore pressure measurement (piezocone). During CPTU sounding, cone resistance $q_{c}$, sleeve friction $f_{s}$, and pore pressure measured behind cone $u_{2}$, with a resolution of $2 \mathrm{~cm}$ were also registered.

Based on the paremeters registered in the field, the following values were calculated

$$
q_{t}=q_{c}+u_{2}^{*}(1-\mathrm{a})[\mathrm{MPa}]
$$

where $q_{c}$ - measured cone resistance, $u_{2}$ - excess of pore pressure measured during the test, $q_{t}-$ cone resistance corrected with regard to the influence of pore pressure, $a$-area ratio of the cone ( $a=0.58$ ), 
$R_{f}=f_{s} / q_{c} * 100 \%$ when a mechanical cone was used,

$R_{f}=f_{s} / q_{t} * 100 \%$ when a piezocone was used.

Parameters derived during the dilatometer tests were calculated according to the formulas of the Marchetti software DMT Elab v. 4.9.0 (Marchetti 1980, Marchetti 1999).

Moduli $E$ were estimated for ice-dammed clays based on the following general formula

$$
E=0.6 * M[\mathrm{MPa}] .
$$

It is based on the compressibility modulus $M$, which has to be determined earlier. The value 0.6 was attained based on the relationship $E / M=\delta$ (for clays) and a better match to the direct values of $E_{M}$ from the pressuremeter test.

Because the constrained modulus $M$ is a function of Young's modulus and Poisson's ratio $v$

$$
M=\frac{(1-v) \cdot E}{(1+v) \cdot(1-2 \cdot v)},
$$

where $v=0.35$ for clays.

The value of the compressibility modulus $M$ was determined using the following formulas

$$
M_{C P T}=\alpha_{m} * q_{c} \text { (Sanglerat 1972) }
$$

where $\alpha_{m}=15$ as the effect of the best match to $M_{D M T}$, $M_{C P T U}=\alpha^{*} q_{n}=\alpha^{*}\left(q_{t}-\sigma_{v 0}\right)$, (Senneset et al. 1989) where $\alpha=18$ as the best match to $M_{D M T}$,

$M_{D M T}=\mathrm{R}_{\mathrm{m}} * \mathrm{E}_{\mathrm{D}}$, according to the formula of Marchetti's software DMT Elab v. 4.9.0.

Values of liquidity index were determined according to the Polish Norm Geotechnics-Field tests

$$
I_{L}=0.242-0.427 * \log _{10}\left(q_{c}\right) .
$$

The coefficient of earth pressure at rest from the $\mathrm{CPT} / \mathrm{CPTU}$ soundings was determined based on the following formulas

$$
K_{0}=0.47^{*}\left(O C R^{0,53}\right) \text {, (Mayne and Kulhawy 1990) }
$$

where $O C R=\sigma_{p}^{\prime} / \sigma_{v 0}^{\prime}$ and $\sigma_{p}^{\prime}=0,33^{*}\left(q_{c}-\sigma_{v 0}\right)$

(Mayne and Holz 1988),

$\sigma_{p, C P T}^{\prime}=0,33\left(q_{c}-\sigma_{v 0}\right)[\mathrm{MPa}]$ (Lunne et al. 1997)

- for the mechanical cone,

$\sigma_{p, D M T}^{\prime}=O C R^{*} \sigma_{v 0}^{\prime}[\mathrm{MPa}]$, where:

$q_{c}$ - mechanical cone resistance CPT [MPa],

$\sigma_{p, C P T}^{\prime}$ - preconsolidation pressure based on the

CPT test $[\mathrm{MPa}]$,

$\sigma_{p, D M T}^{\prime}-$ preconsolidation pressure based on the DMT test $[\mathrm{MPa}]$, $\sigma_{v 0}-$ in situ total vertical stress [MPa], $\sigma_{v 0}^{\prime}-$ effective overburden stress [MPa],

$O C R$ - overconsolidation ratio [-],

$\sigma_{p, C P T U}^{\prime}=O C R / \sigma_{v 0}^{\prime}$,

$O C R=k^{*} \frac{q_{t}-\sigma_{v 0}}{\sigma^{\prime}{ }_{v 0}},($ Lunne et al. 1997) - for the piezocone,

where $k$ varies within $0.2-0.5$, assuming $k=0.40$. Higher values can be applied in the case of strongly preconsolidated soils.

The coefficient of earth pressure at rest from the flat dilatometer test was determined based on the following formula

$$
K_{0 D M T}=\left(K_{D} / 1.5\right)^{0.47}-0.6 .
$$

The overconsolidation ratio from the DMT test can be calculated according to the following formula

$$
O C R_{D M T}=\left(0.5 * K_{D}\right)^{1.56}, \text { where } K_{D}=\left(p_{0}-u_{0}\right) / \sigma_{v 0}^{\prime}
$$

where $K_{D}$ - horizontal stress index,

$p_{0}$ - corrected first reading,

$u_{0}$ - in situ pore water pressure.

The GOUDA device and hardware were used in the test, according to the requirements of appropriate standards.

\section{RESULTS}

The obtained results (Fig. 4, Table 1) show that the value of the pressuremeter modulus $E_{M}$ changes

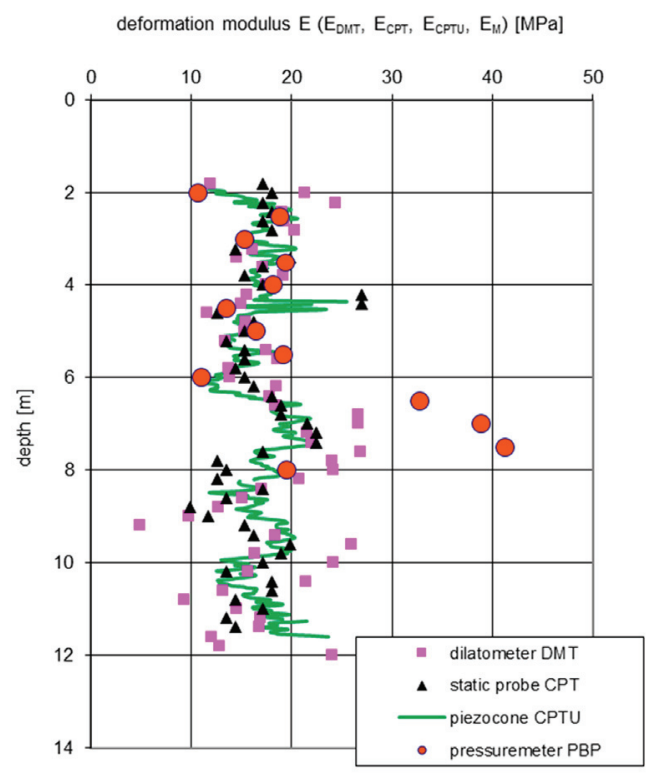

Fig. 4. Deformation modulus in the profile under study 

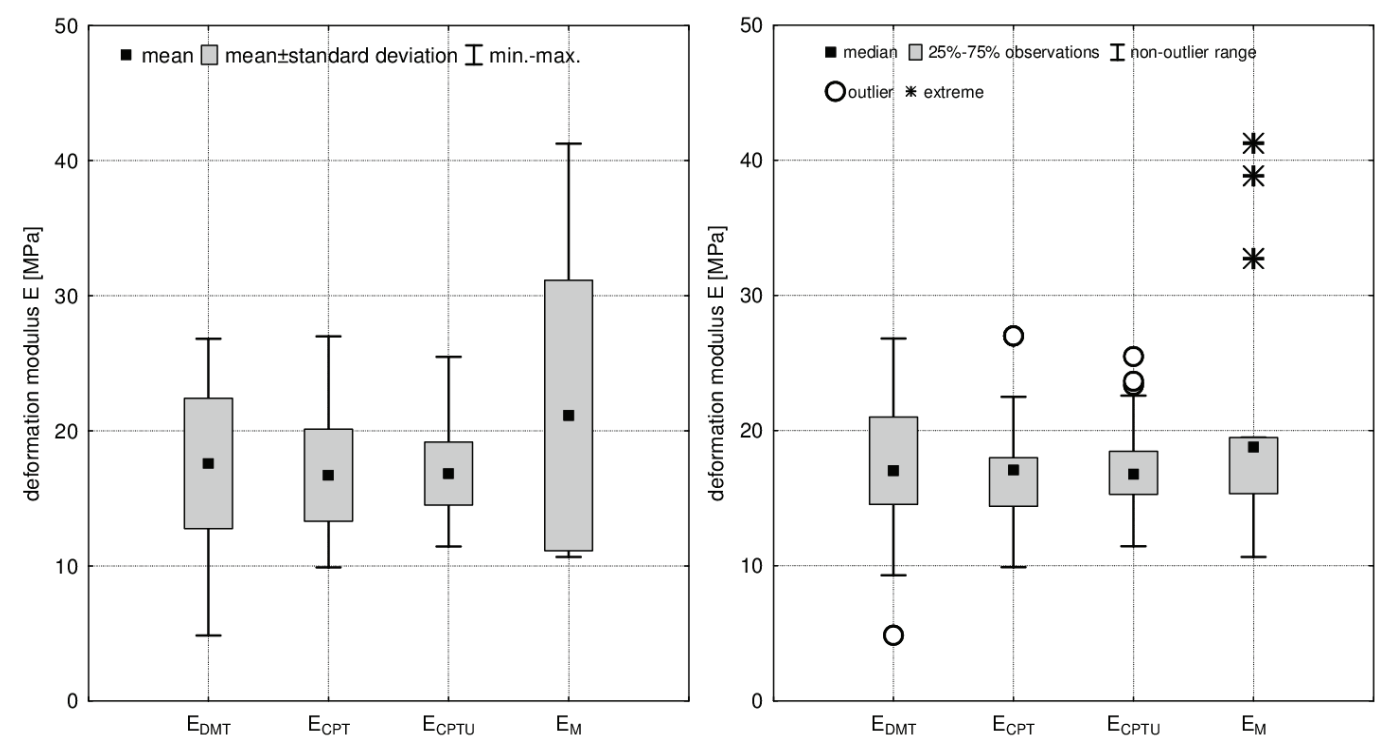

Fig. 5. Statistical comparison of deformation modulus based on in situ tests
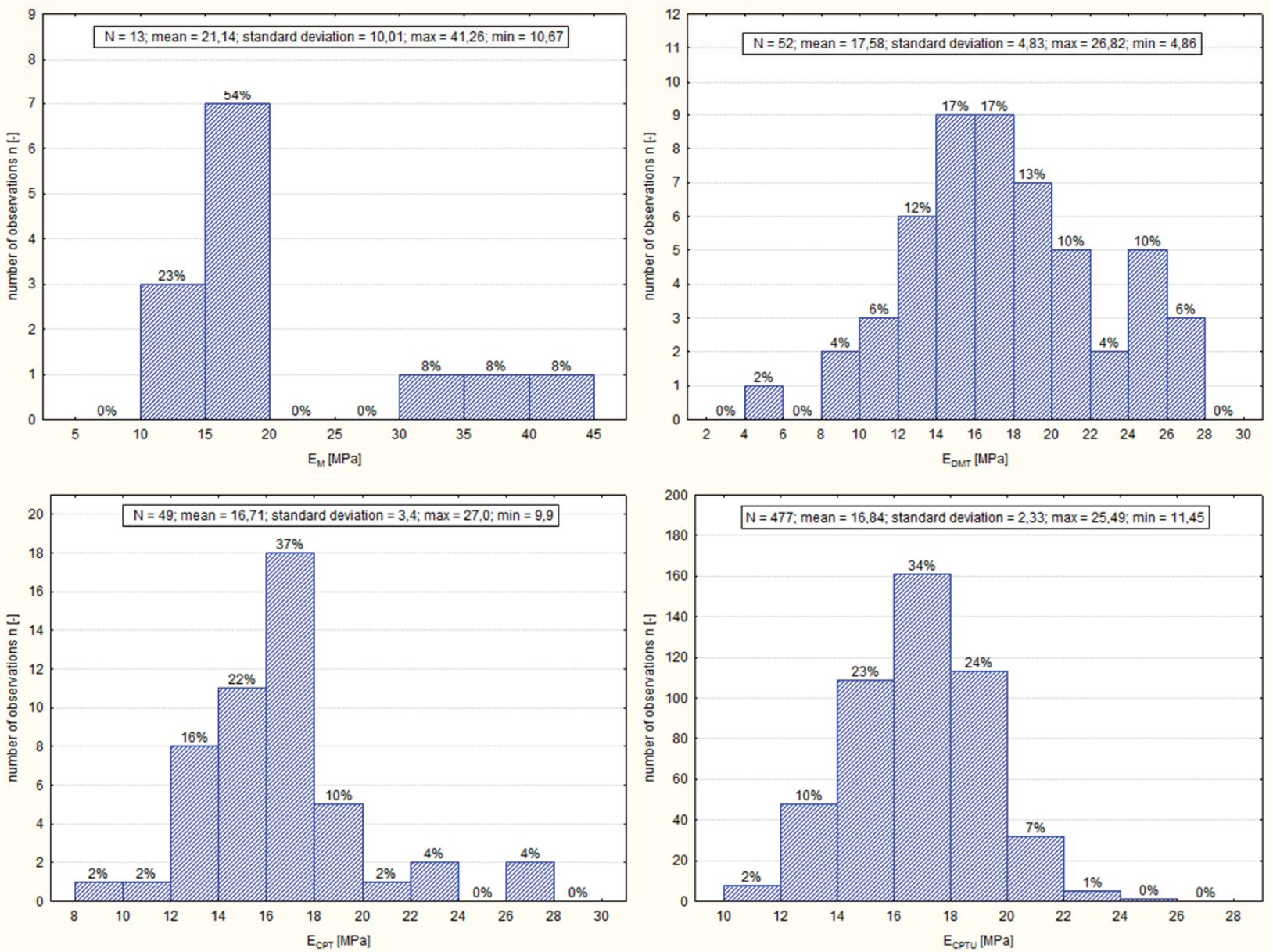

Fig. 6. Frequency and percentage of deformation modulus $E$ in different tests

in the vertical profile and varies from 10.7 to $41.3 \mathrm{MPa}$ (21.1 on average). At a depth ranging from 2 to $6 \mathrm{~m}$ its value shows small variation (from 10.7 to $19.4 \mathrm{MPa}$ ), while at a depth ranging from 6.5 to $7.5 \mathrm{~m}$ it is clearly higher and varies from 32.7 to $41.3 \mathrm{MPa}$. Comparison of the values of $E_{M}$ and the deformation modulus of CPT, CPTU and DMT shows that these values are similar (Fig. 5, Table 2). Values of $E_{C P T}$ 
Table 1. Results of pressuremeter tests

\begin{tabular}{|c|c|c|c|c|c|c|c|}
\hline \multirow{2}{*}{$\begin{array}{c}\text { Depth } \\
(\mathrm{m})\end{array}$} & \multicolumn{2}{|c|}{ Fundamental parameters } & \multicolumn{4}{c|}{ Complementary parameters } \\
\cline { 2 - 8 } & $\begin{array}{c}p_{f} \\
(\mathrm{MPa})\end{array}$ & $\begin{array}{c}p_{l} \\
(\mathrm{MPa})\end{array}$ & $\begin{array}{c}E_{M} \\
(\mathrm{MPa})\end{array}$ & $\begin{array}{c}\sigma_{h s} \\
(\mathrm{MPa})\end{array}$ & $\begin{array}{c}p_{l^{*}} \\
(\mathrm{MPa})\end{array}$ & $E / p_{1}$ & $E / p_{1^{*}}$ \\
\hline 2.00 & 0.40 & 0.67 & 10.7 & 0.020 & 0.65 & 16.0 & 16.5 \\
\hline 2.50 & 0.41 & 0.71 & 18.8 & 0.028 & 0.68 & 26.4 & 27.4 \\
\hline 3.00 & 0.42 & 0.74 & 15.3 & 0.034 & 0.70 & 20.9 & 21.9 \\
\hline 3.50 & 0.38 & 0.67 & 19.4 & 0.042 & 0.63 & 29.1 & 31.0 \\
\hline 4.00 & 0.38 & 0.70 & 18.2 & 0.048 & 0.65 & 25.9 & 27.9 \\
\hline 4.50 & 0.39 & 0.67 & 13.5 & 0.056 & 0.61 & 20.2 & 22.0 \\
\hline 5.00 & 0.40 & 0.69 & 16.4 & 0.063 & 0.63 & 23.7 & 26.1 \\
\hline 5.50 & 0.40 & 0.68 & 19.2 & 0.069 & 0.61 & 28.2 & 31.4 \\
\hline 6.00 & 0.41 & 0.68 & 11.0 & 0.076 & 0.61 & 16.1 & 18.1 \\
\hline 6.50 & 0.70 & 0.96 & 32.7 & 0.083 & 0.88 & 33.9 & 37.2 \\
\hline 7.00 & 0.72 & 0.95 & 38.8 & 0.091 & 0.86 & 41.0 & 45.4 \\
\hline 7.50 & 0.72 & 1.03 & 41.3 & 0.098 & 0.93 & 40.2 & 44.4 \\
\hline 8.00 & 0.43 & 0.81 & 19.5 & 0.104 & 0.70 & 24.1 & 27.7 \\
\hline
\end{tabular}

Table 2. Comparison of the results from three experimental sites from the Warsaw Ice-Dammed Lake

\begin{tabular}{|c|c|c|c|c|c|c|c|c|c|c|c|c|}
\hline 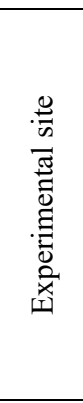 & 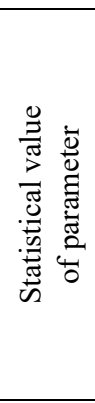 & 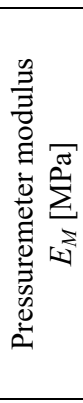 & 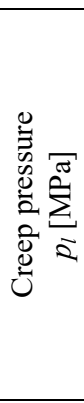 & 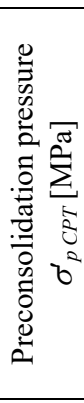 & 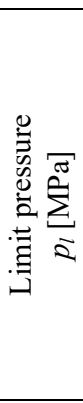 & 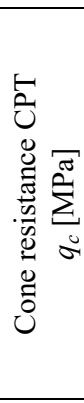 & 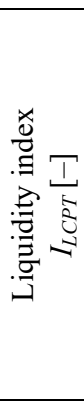 & 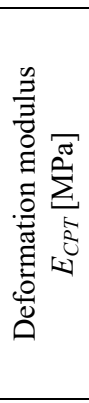 & 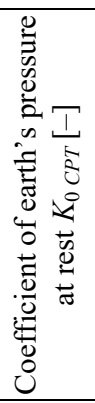 & 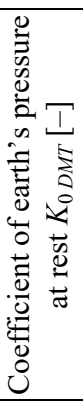 & 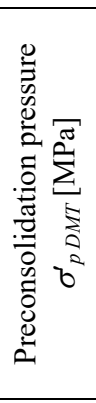 & 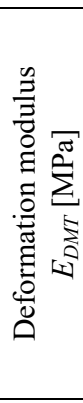 \\
\hline \multirow{3}{*}{ 登 } & $\min$ & 10.7 & 0.38 & 0.31 & 0.67 & 1.1 & 0.04 & 9.9 & 0.90 & 1.17 & 0.37 & 4.9 \\
\hline & mean & 21.1 & 0.48 & 0.57 & 0.77 & 1.9 & 0.13 & 16.7 & 1.51 & 1.66 & 0.62 & 17.6 \\
\hline & $\max$ & 41.3 & 0.72 & 0.96 & 1.03 & 3.0 & 0.22 & 27.0 & 2.41 & 2.20 & 0.95 & 26.8 \\
\hline \multirow{3}{*}{ 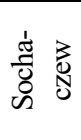 } & $\min$ & 10.5 & 0.22 & 0.20 & 0.38 & 0.7 & 0.06 & 7.8 & 0.90 & 0.97 & 0.29 & 4.3 \\
\hline & mean & 18.5 & 0.45 & 0.58 & 0.75 & 1.9 & 0.13 & 15.5 & 1.36 & 1.52 & 0.59 & 15.8 \\
\hline & $\max$ & 28.7 & 0.67 & 0.84 & 0.96 & 2.7 & 0.32 & 24.3 & 2.09 & 2.15 & 0.84 & 25.2 \\
\hline \multirow{3}{*}{ 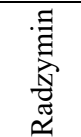 } & $\min$ & 6.7 & 0.24 & 0.36 & 0.55 & 1.2 & 0.05 & 10.4 & 1.19 & 0.98 & 0.26 & 2.0 \\
\hline & mean & 13.4 & 0.40 & 0.61 & 0.70 & 2.0 & 0.12 & 17.7 & 1.46 & 1.54 & 0.48 & 16.2 \\
\hline & $\max$ & 23.7 & 0.58 & 0.89 & 0.87 & 2.9 & 0.22 & 25.7 & 1.84 & 1.97 & 0.71 & 26.7 \\
\hline
\end{tabular}

vary from 9.9 to $27.0 \mathrm{MPa}$ (16.7 on average), values of $E_{C P T U}$ vary from 11.5 to $25.5 \mathrm{MPa}$ (16.8 on average), while values of $E_{D M T}$ vary from 4.9 to $26.8 \mathrm{MPa}$ (17.6 on average). Results from CPT, CPTU and DMT are very close to each other, and, in general, the values of $E_{M}$ are mostly also similar. At a depth ranging from 6.5 to $7.5 \mathrm{~m}$, the values of the moduli are more varied, $E_{M}$ is twice as high as the values of the deformation moduli $E_{C P T}$ and $E_{D M T}$. Direct analyses that would explain the observed discrepancies were not conducted. The reasons may lie in the structural, early diagenetic deformation taking place irregularly within the soils after its deposition. A synthetic summary of the results is shown in Fig. 7 and Table 1. Selected pressuremeter curves are shown in Figs. 8 and 9. Figure 6 shows the histograms of the deformation modulus evaluated from field tests. Furthermore, Table 2 includes data from other experimental sites in the area of the Warsaw Ice-Dammed Lake. Based on the results of the static probe tests, the clays under study are stiff. The liquidity index $I_{L}$ ranges between 0.04 and 0.22 (average $=0.12$ ).

Creep pressure $p_{f}$ characterizes the beginning phase of plastic deformation in the PMT test. The 
Faculty of Geology University of Warsaw

Al. Żwirki i Wigury 93 02-089 Warsaw

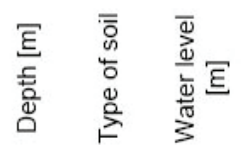

\section{MENARD PRESSUREMETER TEST}

according to EN ISO 22476-4

Site

Creep pressure $\mathrm{p}_{\mathrm{i}}[\mathrm{MPa}]$

lłów

Limit pressure $\mathrm{p}_{1}[\mathrm{MPa}]$

Pressuremeter modulus $\mathrm{E}_{\mathrm{M}}[\mathrm{MPa}]$

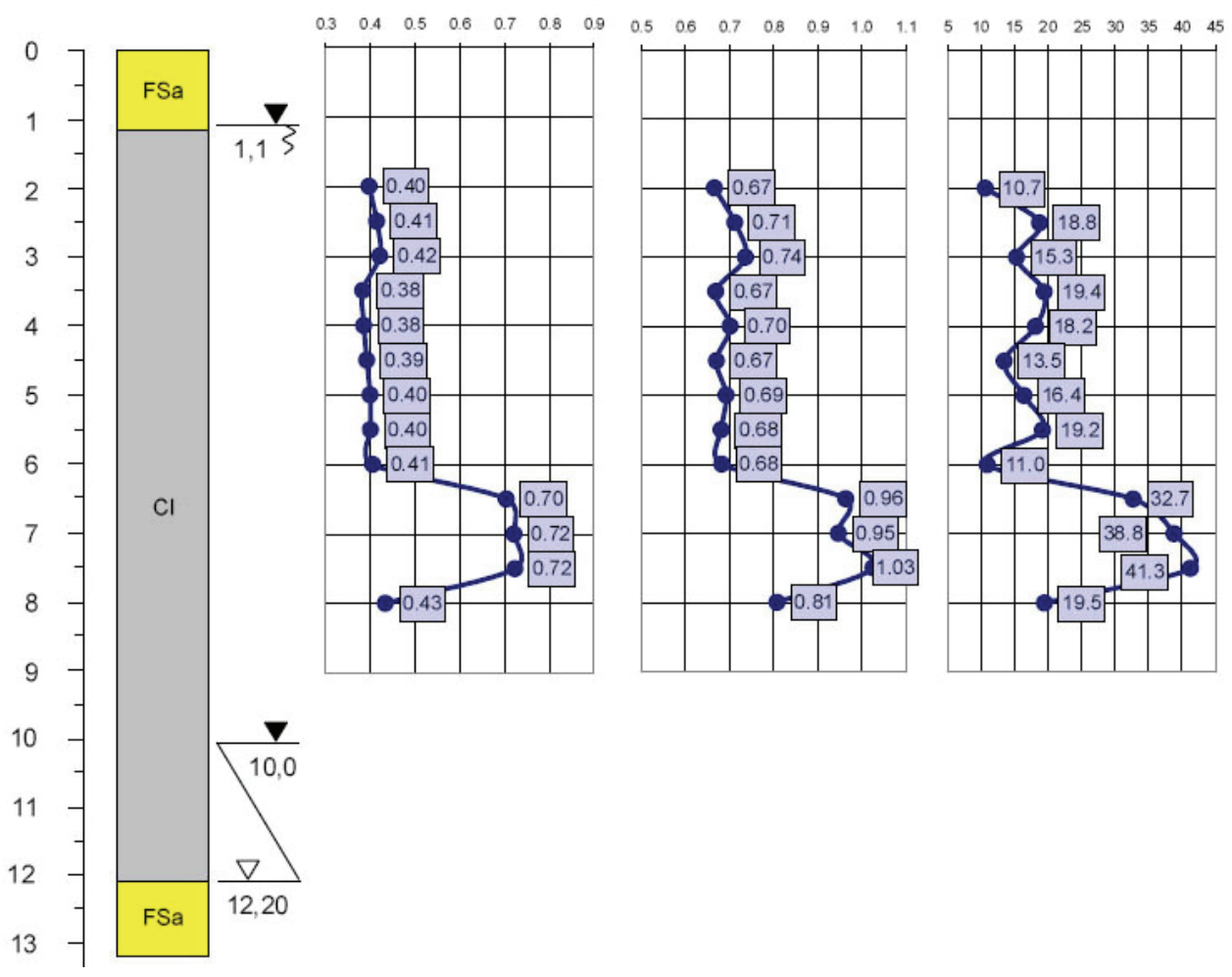

Fig. 7. Summary of pressuremeter tests results

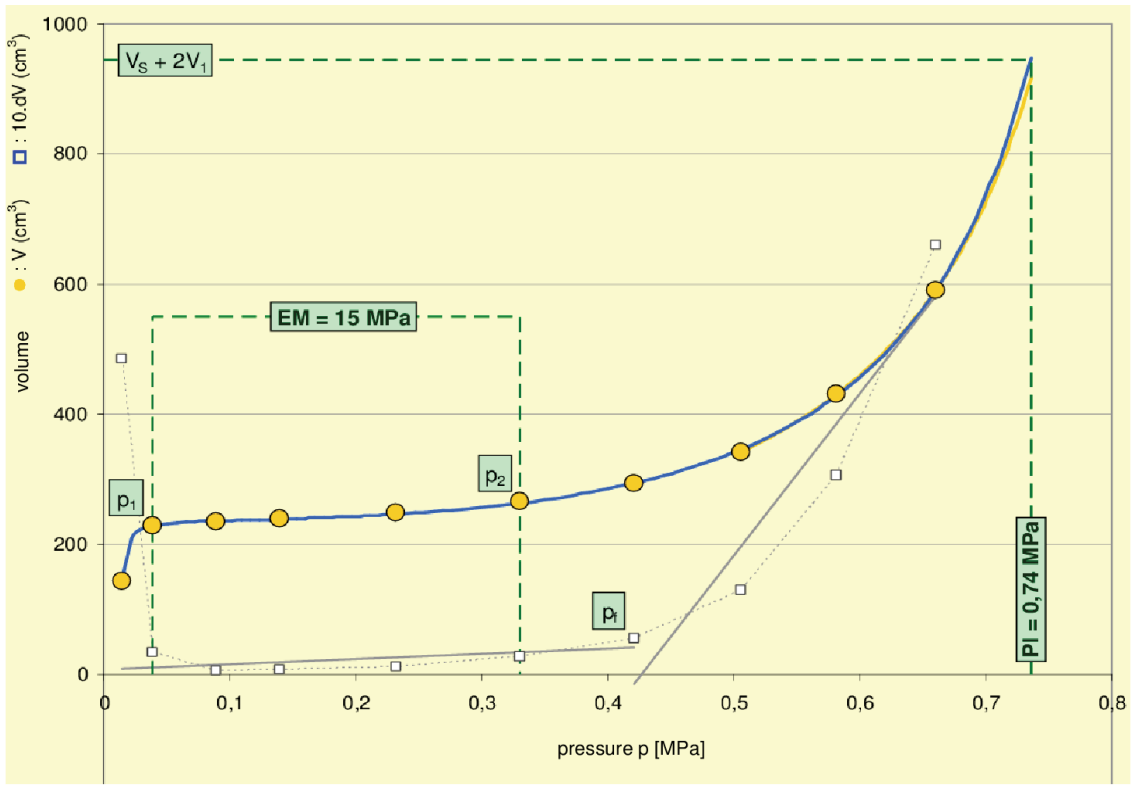

Fig. 8. Pressuremeter curve, depth $3 \mathrm{~m}$ 
values of this parameter obtained for the studied clays under study vary from 0.38 to $0.72 \mathrm{MPa}$ (Table 1 , Fig. 10).

Boxplots were used to compare and illustrate the spread of statistical parameters of preconsolidation pressure and creep pressure (Fig. 11). conditions, different moduli of compressibility are obtained. Each curve shows a completely different trend of changes with increasing load - its values vary depending on the range of the applied loads. This indicates the complexity of the issue of determining soil deformability.

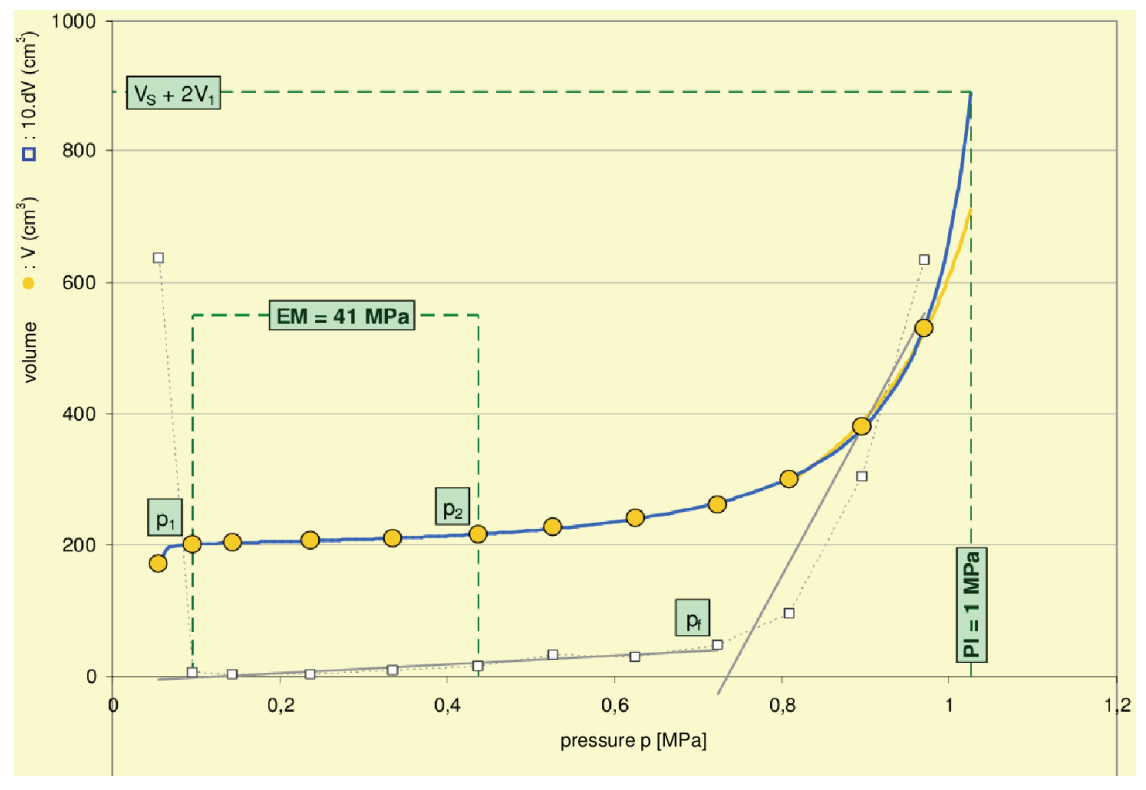

Fig. 9. Pressuremeter curve, depth $7.5 \mathrm{~m}$

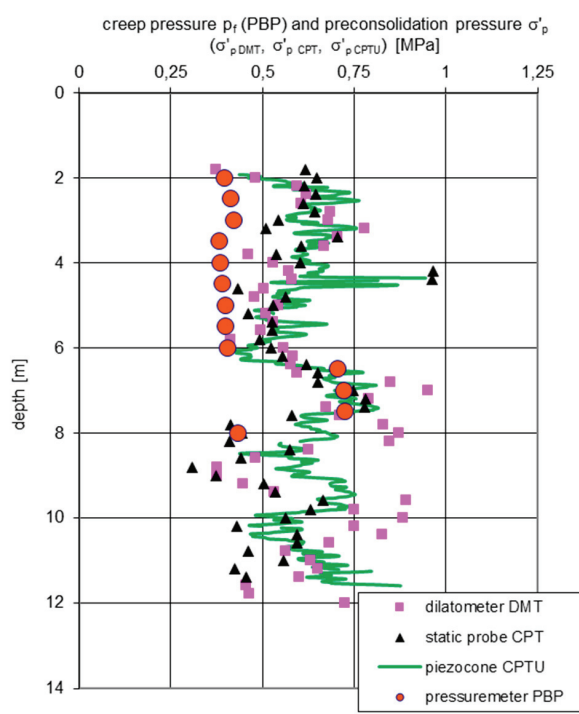

Fig. 10. Creep pressure and preconsolidation pressure in the study profile
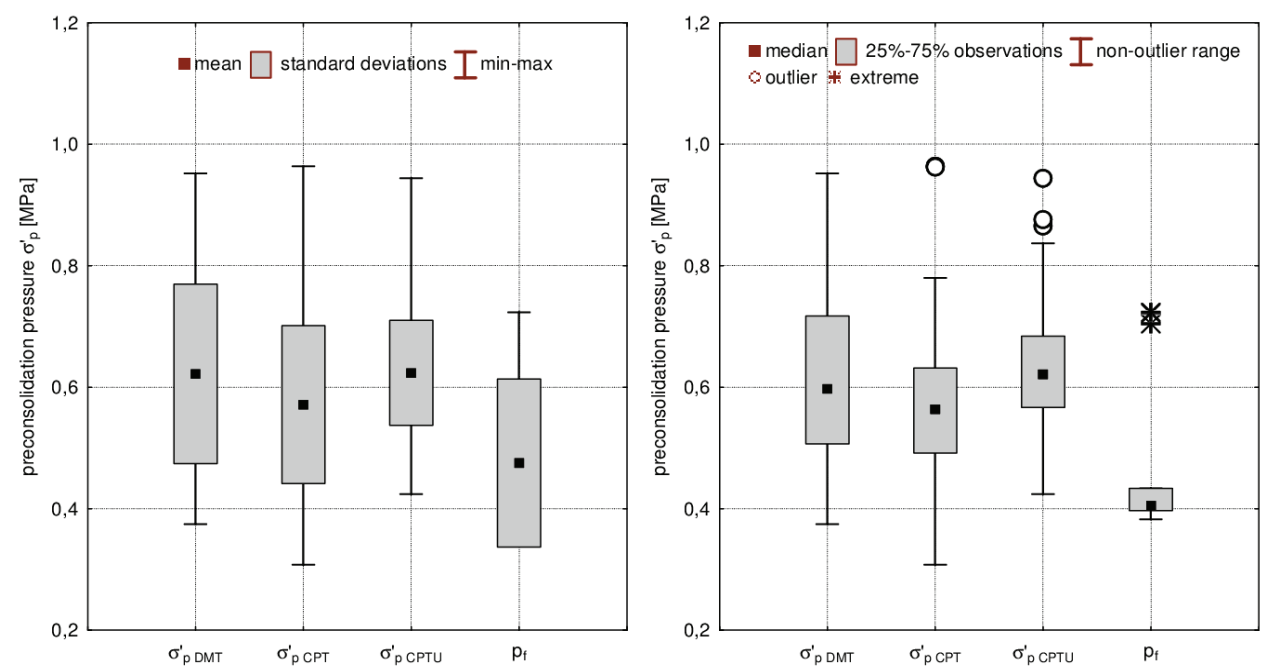

Fig. 11. Boxplots of preconsolidation pressure and creep pressure

\section{INTERPRETATION AND DISCUSSION}

Depending on the test conditions, i.e., on the load method and the possibility of deformation, the compressibility of soils has a different character. The curves show (Fig. 12) that depending on the research
Results of pressuremeter test are similar to the C-curve shown in Fig. 12. The pressuremeter module decreases with increasing load range. It is determined for the range of applied pressures described as $p_{1}$ (standard pressure referring to the beginning of the flat section of the pressuremeter curve) and $p_{2}$ (standard pressure referring to the termination of the flat 
section of the pressuremeter curve). Additionally, the load range for determining the pressuremeter modulus can be chosen during the interpretation of the results. However, in this case, the load range should be within the range of pseudoelastic deformation (pseudoelastic phase). The pressure test procedure allows the relationship between the pressure and the reaction of the soil to be obtained, in the widest range of loads from the research tools used in the study. It is a direct, true observation of behaviour of the borehole walls under a gradually applied load.

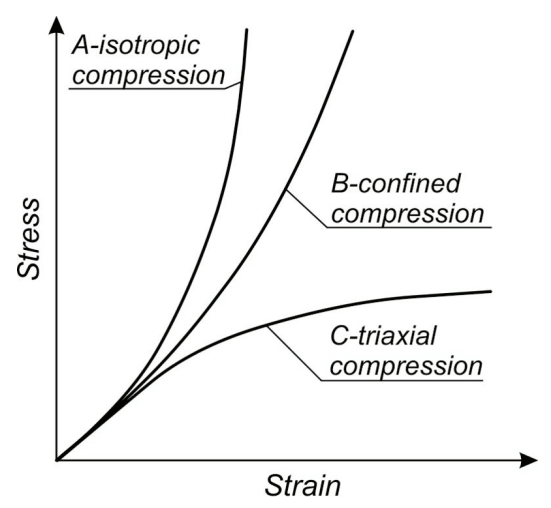

Fig. 12. Comparison of different stress-strain curves

In the author's opinion, the observed differences are due to the different methods of in situ testing and partly due to the natural variability of the deposits studied. Among the causes contributing to the differences in the values of the deformation modulus from different test methods, the following factors can be distinguished:

- The deformation moduli determined on the basis of CPT and CPTU tests are values obtained empirically and not in a real way, since the range of loads and deformations for which the moduli have been determined are unknown. Depending on the correlations and equations used in the calculations, different values representing the soil stiffness can be obtained. DMT sounding is a much better tool in this case. The conditions in which the test is conducted allow the displacement membranes and the accompanying stresses to be measured. Assessment of soil stiffness is based mainly on two measured parameters, i.e., $p_{0}$ and $p_{1}$.

- During the CPT test, the soil structure is destroyed around the probe caused by direct cone penetration. The calculated deformability is related to the results of the soil structure resistance to failure. Thus, the essential work of the probe takes place in the phase of destruction of the soil structure. CPT test mode does not even simulate conditions determining the value of the real deformation modulus. Since the CPT procedure does not allow one to obtain information about the range of loads, in which the modulus is determined, it has to be remembered that it is an empirical value only, determined on the basis of the search for the best match to the benchmark data (laboratory tests, dilatometer tests, etc.)

- During DMT tests, serious disturbance in the soil structure occurs directly in the dilatometer blade zone, even before the correct phase of the study starts. Therefore, the pressures which are generated during the test are in the post-failure zone and refer to the displacement of the diaphragm by about $1.1 \mathrm{~mm}$. This test method represents an intermediate quality of assessment of the soil stiffness, among the presented methods.

- For the PMT test, the borehole was drilled carefully by hand to minimize borehole wall disturbance, which allows the observation of soil behavior in the phase of the pre-failure zone. The PMT probe gradually applies pressure on the borehole walls of very good quality. Moreover, the PMT test is performed without generating initial pressure, which accompanies a fairly rapid DMT and CPT test. As a result of the borehole, short relaxation appears in the soils. Therefore, the results are closer to reality in comparison to the CPT or DMT tests and the obtained values of the pressuremeter modulus refer to the total shear strength of the undisturbed glaciolacustrine clays. It should be emphasized that the determinants included: state of soil, grain size distribution, careful drilling by hand and cutting off the groundwater flow to the borehole. In other types of soil and in different texture these conditions cannot be met.

The deformation modulus determined for the initial phase of compressibility (before failure) is higher than the one for a subsequent range of deformations (after failure). This is consistent with the theoretical model on the compressibility of cohesive soils (Fig. 12). The modulus $E_{M}$ is determined directly as it is accompanied by the actual and the measured load (pressure). The load range, for which $E_{M}$ was determined, is on average between 70 and $290 \mathrm{kPa}$. Depending on the quality of correlation with $E_{C P T}$ and $E_{D M T}$, it is the interval indicating an approximate stress range of corresponding moduli. Due to the short time of testing, the CPT and DMT tests do not allow for the dissipation of the generated excess pore pressure in clays or tills. Therefore, there should not be any change in the soil volume. The modulus obtained is therefore a shear modulus and not a compressibility modulus. However, during the pressuremeter test, the soil con- 
ditions are the closest to the criteria required for compressibility tests - the load range and the range of deformations are known.

Moreover, focus should be drawn to the conditions at which the tests are conducted. The pressuremeter modulus and the dilatometer modulus are determined in a horizontal direction. Because the varved clays are characterized by structural anisotropy, slightly different values of the compressibility parameters are expected horizontally. Nevertheless, results of some studies indicate that there are no significant differences in the values of compressibility parameters determined horizontally and vertically (Stefaniak 2010). The influence of the anisotropy and the texture of varved clays is evident with regard to the strength parameters/properties (Młynarek 1982, Młynarek and Horváth 1990).

Values of creep pressure $p_{f}$ were compared with the preconsolidation pressure $\sigma_{p}^{\prime}$, which in the light of current research (Burland et al. 1996, Zawrzykraj 2007) should be rather interpreted as yield pressure $\sigma_{y}^{\prime}$. The analysis leading to determine the load, to which the soil was subjected in its geological history is difficult. This is due to structural changes in the sediment since its accumulation (weathering, diagenesis) (Boone and Lutenegger 1997, Zawrzykraj 2004). Determination of creep pressure $p_{f}$ and yield pressure $\sigma_{y}^{\prime}$ is based on a similar principle. In both cases, it signifies the load at which the pseudoelastic deformation ends and plastic deformation begins. Further research increasing the statistical sample enables finding the expected relationships, and the creep pressure will help to estimate the yield pressure. The similarity between the values of creep pressure $p_{f}$ and preconsolidation pressure $\sigma_{p}^{\prime}$ has been noticed by many researchers (e.g., Mori and Tajima 1964, Lukas and Le Clerk de Bussy 1976). Figure 10 shows creep pressure and preconsolidation pressure in the vertical profile of the clays under study. Statistical comparison of these parameters is presented in Fig. 11.

Limit pressure $p_{l}$, also known as the pressuremeter bearing capacity limit, is reached at the time of doubling the volume of the expanding cavity $\left(V_{s}+2 V_{1}\right.$, where $V_{s}$ - initial volume of the measuring cell, $V_{1}-$ difference between the volume of the cavity and the initial volume of the measuring cell (Baguelin 1978, Tarnawski 2007). Values of limit pressure $p_{l}$ obtained in the PMT test vary from $0.67 \mathrm{MPa}$ to 1.03 at the top of the profile to 1.03 at the base (Table 1, Fig. 7). These values are used to determine the bearing capacity of the ground (Baguelin 1978, Frankowski 2003, Tarnawski 2007).
The report currently obtained from the PMT test compiled in APAGEO software contains the values of the horizontal stress $p_{o}\left(\sigma_{h s}\right)$. However, it is calculated for an assumed value of the coefficient of earth's pressure at rest $K_{0}$, which attains 0.5 . The value of horizontal stress is calculated according to the formula

$$
\sigma_{h s}=K_{0} *\left(\sigma_{v 0}-u\right)+u,
$$

where $\sigma_{h s}$ - horizontal stress, $\sigma_{v 0}-$ vertical overburden stress, $u$ - pore pressure.

These assumptions have been made in view of the difficulties of interpretation of the actual horizontal stress $p_{0}$ based on the pressuremeter curve. It seems that for the appropriate quality of the borehole wall, the beginning of the flat section of the pressuremeter curve corresponds to the original horizontal stress $\sigma_{h s}$. Comparative studies of the obtained values of $\sigma_{h s}$ with values previously determined in laboratory tests have demonstrated that they differ significantly from each other (Tarnawski 2007). Values obtained from pressuremeter tests were lower and decreased with depth. It was found that the beginning of the pseudoelastic phase is rather an indicator of the quality of the borehole walls than the value of horizontal stress. Determination of horizontal stresses and thus $K_{0}$ is particularly difficult (Młynarek et al. 2006). This is particularly true in the case of the varved texture of the soils under study. According to its definition it is determined at increasing vertical stress while there is no possibility of vertical deformations. Presently it is not possible to determine directly horizontal stresses in soil using in situ test methods. Nowadays, the methods rely on the analysis of deformation during load application. Then the shape of the curves is linked to the horizontal stresses. However, this methodology may lead to significant errors, which was previously selected as an example of determining the preconsolidation load. A similar methodology is used to define the horizontal stress. Field methods are correlated with laboratory tests. This means that in many cases the compatibility of different test methods is based on false assumptions. In addition, it should be remembered that during fieldwork, the setting of horizontal stress takes place in a different state of stress and strain than in the laboratory. The CPT test method does not allow for direct measurements but uses appropriate correlations. Interpretation of DMT results relies on the record of the dilatometer horizontal stress index.

Nevertheless all the methods relate to the determination of horizontal stress based on the observation of 
the load, at which plastic deformation of soil structure starts. For the study clays the results obtained from CPT, CPTU and DMT tests show significantly higher values than those obtained from the PMT test (Fig. 13, Table 1). In the light of the issues presented above, these data are overestimated and the actual horizontal stress ratio needs to be clarified in further investigations.

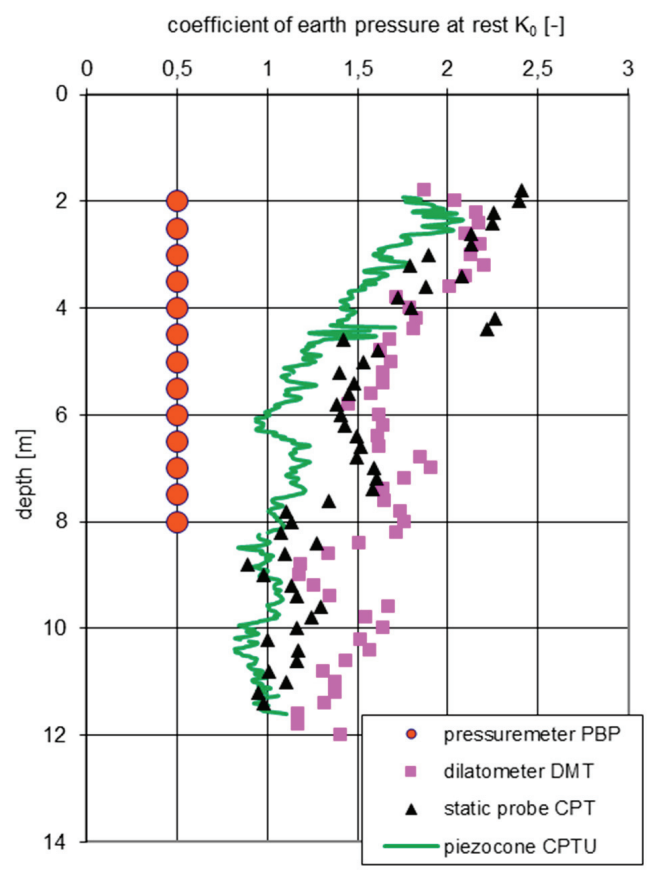

Fig. 13. Coefficient of earth's pressure at rest in the study profile

\section{CONCLUSIONS}

Based on the results of in situ tests and their analysis, the mechanical parameters of varved clays have been evaluated. They are part of the regional variation characteristics of clays. Particular attention was given to the deformability of clays, which shows variation in the vertical profile. Trends and relationships shown in the graphs obtained in relation to the research methodology and the natural variability of the clays under study were compared and characterized.

The variability of basic mechanical parameters in vertical profile of the ice-dammed clays was determined as a result of selected in situ tests. Comparison of deformation moduli obtained from different types of field tests has demonstrated that the results obtained are compatible. Analysis of the obtained values of horizontal stress and the coefficient of earth's pressure at rest allows us to formulate a thesis that the values obtained from CPT and DMT tests are overes- timated. This is related to the diagenetic processes reinforcing the structure of the sediment since the time of its deposition. Significant differences in the values of these parameters depending on the test method were found. While the values of $K_{0}$ obtained from CPT and DMT tests are similar, for the PMT test the $K_{0}$ value was assumed as being equal to 0.5 by the device and software producer - APAGEO Company. This concept was created because of the difficulties of horizontal stress interpretation from the pressuremeter curve. Therefore, currently an increase of horizontal stress in proportion to depth is assumed, and is mostly associated with weight of soil.

Mechanical properties of the varved clays studied are highly compatible with the results obtained in another experimental site (Table 2) (Zawrzykraj 2004, Zawrzykraj 2011). Thus, it can be concluded that the geological and engineering characteristics of varved clays suggest a similar geological history (loadings, consolidation, erosion). It also means that there are similar conditions of deposition and diagenesis within the selected research sites. Thus, the data obtained are consistent and confirm that the experimental sites belong to one ice-dammed lake covering the areas of the Warsaw Basin during the Last Glaciation.

\section{REFERENCES}

[1] Baguelin F., JÉzÉQeel J.F., Shields D.H., The Pressuremeter and foundation engineering, Trans. Tech. Publications., Clausthal, 1978.

[2] Boone J., Lutenegger J., Carbonates and cementation of glacially derived cohesive soils in New York State and southern Ontario, Canadian Geotechnical Journal, 1997, 34, 534-550.

[3] Burland J.B., Rampanello S., Georgiannou V.N., CALABRESHI G., A laboratory study of the strength of four stiff clays, Géotechnique, 1996, 46, 3, 491-514.

[4] DZIERŻEK J., (ed.) Relief and Quatenary sediments of centraleastern Poland - a guide to the field course in geomorfology and Quatenary geology, Faculty of Geology, University of Warsaw, Warsaw 2001, 41-51.

[5] FRANKOWSKI Z., Interpretation of dynamic sounding and pressuremeter test results, [in:] Seminar on modern methods of soil investigation, Building Research Institute, Warsaw 2003, (in Polish).

[6] Gambin M., Magnan J.P., Mestat P., 2005, ISP - Pressio 2005 - International Symposium 50 years of pressuremeters, Marne-la-Valléé, Vol. 1, Vol. 2. Presses Ecole Nationale Ponts et Chaussées, Paris 2005.

[7] Kozydra Z., Marzec M., Ruszkowska H., Catalogue of selected clay deposits for building ceramics in Poland (ed. Kozłowski S.), Wydawnictwa Geologiczne, Warsaw 1977, (in Polish with English Summary).

[8] LuKas G.L., LeClerC De Bussy B., Pressuremeter and Laboratory Test Correlations for Clays, Journal of the Geotechnical Engineering Division, American Society of Civil Engineers, 1976, 102, GT 9, September: 945-963. 
[9] Lunne T., Robertson P.K., Powell J.J.M., Cone Penetration Testing in geotechnical practice, E\&FN SPON, London 1997.

[10] Marchetti S., In Situ Tests by Flat Dilatometer, Journal of the Geotechnical Engineering Division, ASCE, Vol. 106, No. GT3, Proc. Paper 15290, 1980, 299-321.

[11] MARChetTI S., The Flat Dilatometer and its applications to Geotechnical Design, International Seminar on DMT held at the Japanese Geot. Society, Tokyo, 12 Feb 1999, pp. 90.

[12] Mayne P.W., Holtz R.D., Profiling stress history from piezocone soundings, Soils and Foundations, 1988, 28, 1, 16-28.

[13] Mayne P.W., Kulhawy F.H., Direct and indirect measurements of in-situ Ko in clays, Transportation Research Record 1278, Washington D.C., 1990, 141-149.

[14] Merta T., Extraglacial deposits of the Warsaw Ice-Dammed Lake (younger Pleistocene), Mazovia Lowland, Central Poland, Acta Geologica Polonica, 1978, 28, 241-271.

[15] Mori H., TAJIMA S., The Application of the Pressiometre Method to the Design of Deep Foundations, Soil and Foundations, Tokyo, 1964, 4, 2, 34-44.

[16] MŁynarek Z., NiedZielski A., Tschuschke W., The static penetration results in varved clay, Proc. 2 nd Eur. Symp. on Penetration Testing. Balkema, Amsterdam, 1982, 715-721.

[17] MŁynarek Z., TschuschKe W., WierzBicki J., Assessment of coefficient of earth pressure at rest based on DMT and CPTU, (in Polish with English summary). Budownictwo - Zesz. Nauk. Politechniki Białostockiej, 2006, 28, 1, 213-226.

[18] MŁYNAREK Z., WierzBicki J., Nowe możliwości i problemy interpretacyjne polowych badań gruntów, [in:] Współczesne problemy geologii inżynierskiej w Polsce, R. Radaszewski (ed.), Bogucki Wyd. Naukowe Poznań, 2007, 97-118.

[19] MŁynarek Z., Horváth G., Shear parameters of varved clay, Period. Polytech. Civil Eng., 1990, Vol. 34, No. 3-4, 215-223.

[20] MYŚLIŃSKA E., Influence of sedimentary conditions and of diagenesis of varved clays of the Middle-Polish Glaciation from the Mazovian area upon their engineering-geological properties, Biuletyn Geologiczny Uniwersytetu Warszawskiego, 1965, 7, 3-106, (in Polish with English Summary).
[21] Różycki S.Z., Pleistocene of Central Poland, Wydawnictwo Naukowe PWN, Warsaw 1967, (in Polish).

[22] SANGLERAT G., The penetrometer and soil exploration, Elsevier, Amsterdam-Oxford-New York 1972.

[23] Senneset K., SAndven R., JanBu N., The evaluation of soil parameters from piezocone tests, Transportation Research Record, 1989, 1235, 24-37.

[24] STEFANIAK K., The constrained modulus of varved clay from in situ tests, [in:] Soil parameters from in situ and laboratory tests, E. Dembicki, J. Komisarek (ed.), Wyd. Uniwerstytetu Przyrodniczego w Poznaniu, 2010, 281-290.

[25] TARnAwski M., Errors in pressuremeter tests, Przegląd Geologiczny, 1985, 1, 38-41, (in Polish with English Summary).

[26] TARNAwSKI M., Application of pressuremeter test in soil investigations, Wydawnictwo Naukowe PWN, Warsaw 2007, (in Polish).

[27] Wierzbicki J., Paluszkiewicz Re., Paluszkiewicz Ry., Application of cone penetration test in the analysis of stratigraphy of cainozoic sediments, Quastiones Geographicae 25A, Adam Mickiewicz University Press, Poznań 2006, 83-88.

[28] Wierzbicki J., Paluszkiewicz Re., Paluszkiewicz Ry., Lithological analysis of the Ztocieniec proglacial lake sediments based on cone petration test results, [in:] Reconstruction of morphological processes dynamics - landforms and deposits, Warsaw 2007, 427-438, (in Polish with English Summary).

[29] ZAWRZYKRAJ P., Analysis of consolidation state of varved clays in the Sochaczew and Radzymin area, Dissertation, University of Warsaw 2004, (in Polish).

[30] ZAWRZYKRAJ P., Evaluation of the preconsolidation effects on the basis compressions studiem of ice-dammed Claus from the vicinity of Warsaw, Geologos, 2007, 11, 499-508, (in Polish with English Summary).

[31] Zawrzykraj P., Characteristic of mechanical properties of ice-dammed clays from Radzymin area based on pressuremeter tests, Biuletyn PIG, 2011, 446/2, 429-436, (in Polish with English Summary). 